\title{
Landspítalinn - tifandi tímasprengja?
}

\section{Ómar Sigurvin Gunnarsson}

læknir á Landspítala og formaður Félags almennra lækna

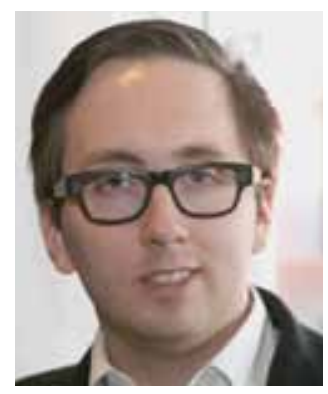

omarsg@landspitali.is

Langvarandi niðurskurður, aukið álag, stöðug undirmönnun, léleg starfsaðstaða, bágur húsa- og tækjakostur: Allt petta hefur leitt til pess að ástandið á Landspítala, stærsta vinnustað landsins, er líkt og tifandi tímasprengja. Með elju starfsfólks og dugnaði hefur verið haldið stöðugt áfram; hlaupið hraðar, unnið lengur, fleirum sinnt af færri höndum. Lítið hefur purft til að raska viðkvæmu jafnvæginu, af litlum neista verður oft mikið bál. Sú hefur verið raunin innan stofnunarinnar; neistinn frá haustmánuðum hefur leitt af sér mikið bál sem ekki sér fyrir endann á.

Mitt í pessu óvissuástandi hefur lítið heyrst í læknum. Hverju sætir pað? Eru læknar ánægðari með ástandið en aðrar stéttir? Er læknum umbunað umfram aðra?

Síður en svo! Almennir læknar hafa frá árinu 2010 verið ein óánægðasta stétt Landspítala, ásamt geislafræðingum og vaktmönnum, samkvæmt mælingum vinnuveitanda. ${ }^{1}$ Árið 2012 bættust svo sérfræðingar í pennan hóp. ${ }^{2}$ Stofnunin hefur ekki gripið til neinna úrræða til að reyna аð bæta starfsskilyrði eða starfsánægju pessa hóps. Petta hefur leitt til pess að sífellt erfiðara reynist að fá lækna til að manna stöður sem losna og stöðugt fleiri læknar halda utan til starfa, að hluta til eða alveg. Nýleg könnun bendir til pess að stór hluti íslenskra lækna erlendis ætli sér ekki að snúa aftur til starfa hérlendis í óbreytt ástand. ${ }^{3}$ Stjórnvöld og yfirstjórn spítalans hafa skellt skollaeyrum við aðvörunarorðum lækna og ekki brugðist við peim vanda sem landflótti lækna er, og ef ekki verður gripið inn í blasir ófremdarástand við.

En hvers vegna eru læknarnir óánægðir?

Stöðug undirmönnun hefur leitt til pess að teymi stækka og hver læknir ber ábyrgð á alltof mörgum sjúklingum, en einungis priðjungur lækna telur sig geta klárað verkefni sín svo fullnægjandi sé, samkvæmt áðurnefndri könnun. Раð ógnar öryggi sjúklinga, auk pess að draga úr starfsánægju og valda líkamlegum og andlegum álagseinkennum, en allt að 89\% lækna lýsa slíkum einkennum í tengslum við störf sín. Engar starfslýsingar eru til fyrir lækna til að styðjast við, sem auðveldað gætu peim að afmarka störf sín, enda telja 25-50\% almennra lækna sig ekki vita til hvers er ætlast af peim í starfi. Slíkt er ekki líklegt til að auka skilvirkni né starfsánægju. Engar álagsmælingar eru gerðar fyrir lækna og mönnunarpörf ekki reiknuð og getur spítalinn pví stöðugt leyft sér að bæta verkefnum og sjúklingum á lækna, og vonað að ekkert alvarlegt komi upp á.

Við pessi vandamál bætist svo óviðunandi starfsaðstaða, en ekki er gert ráð fyrir læknum við skipulag búnings- eða vinnuaðstöðu. Tækjakostur stofnunarinnar er bágur, enda hafa fjármunir til tækjakaupa verið af skornum skammti. Læknar hafa bent á að úr sér gengin tæki og ódýrari tæki sem keypt hafa verið, geti ógnað öryggi sjúklinga, auk pess sem pau geta tafið greiningu og meðferð. ${ }^{4}$ Læknum á Íslandi er ekki launað fyrir störf sín í samræmi við lengd náms, ábyrgð og álag í starfi. Stjórnmálamenn, nú síðast hæstvirtur velferðarráðherra í Kastljósi 20. september síðastliðinn, hafa dregið upp pá tálsýn að læknar hérlendis hafi pað svo gott; séu sannkölluð hálaunastétt. Ef staðreyndir málsins eru skoðaðar sést að læknar hafa dregist aftur úr í launapróun síðustu ára. Frá 2007 hafa meðaldagvinnulaun ýmissa háskólastétta hækkað um 28-43\%, en læknar hafa hækkað mun minna. ${ }^{5}$ Grunnlaun lækna eftir 6 ára háskólanám eru nú 340.734 krónur eftir hækkunina 1. mars. Рað er pví ljóst að laun lækna eru hvorki samkeppnishæf innanlands né utan, par sem pau eru yfirleitt tvisvar til prisvar sinnum hærri.

Landspítalinn er staddur á krossgötum. Einungis priðjungur lækna mælir með stofnuninni sem góðum vinnustað. Síaukin óánægja og flótti lækna ógna stöðu stofnunarinnar. Stjórnvöld og yfirstjórn spítalans verða að leggja allt kapp á að snúa pessari próun við, ef við ætlum áfram að halda hér uppi heilbrigðiskerfi á heimsmælikvarða. Eru ráðamenn landsins virkilega tilbúnir að horfa aðgerðalausir á heilbrigðiskerfið molna og mygla innan frá, líkt og byggingarnar við Hringbraut? Stefnt hefur verið að pví að byggja par öflugt háskólasjúkrahús, til framtíðar. En er hægt að reka öflugt háskólasjúkrahús án lækna?

Ég vona svo sannarlega að við purfum ekki að láta á pað reyna!

\section{Heimildir}

1. Starfsumhverfiskönnun LSH 2010. Mannauðssvið Landspítala - háskólasjúkrahúss, Reykjavík 2010.

2. Sigurjónsson $H$. Vaxandi óánægja meðal sérfræðinga Landspítala. Læknablaðið 2012; 98: 600-2.

3. Fáa lækna langar aftur heim. Fréttablaðið 2013; 5: 1/66.

4. Jónsdóttir P. Tækjabúnaður Landspítala: umhyggja - fagmennska - öryggi - frambróun? Læknablaðið 2012; 98: 447.

5. Meðallaun starfsmanna ríkisins. Fjármálaráðuneytið 2012. fjarmalaraduneyti.is/verkefni/starfsmenn_rikisins / kjarasamningar/medallaun/- febrúar 2013.

Landspítali - a ticking time bomb?

Ómar Sigurvin Gunnarsson Resident at Landspítali Chairman of The Icelandic association of junior doctors 